\title{
EVALUASI MASTITIS SUBKLINIS PADA SAPI PERAH DI PETERNAKAN RAKYAT KAPUPATEN TANGGAMUS MENGGUNAKAN UJI MASTITIS DAN JUMLAH SEL SOMATIK
}

\section{Evaluation of Subclinical Mastitis in Dairy Cows at People of Tanggamus Regency Farms with Mastitis Test and Somatic Cell Count}

\author{
Dian Cahya Hadi, Veronica Wanniatie, Arif Qisthon, dan Purnama Edy Santosa \\ Department of Animal Husbandry, Faculty of Agriculture University of Lampung \\ Jl. Prof. Soemantri Brojonegoro No.1 Gedung Meneng Bandar Lampung 35145 \\ e-mail : riantocahyahadi@gmail.com
}

\begin{abstract}
This study aimed to determine the presence or absence of subclinical mastitis cases with mastitis test IPB1 and somatic cell count calculation of the Breed method for dairy milk farm in Tanggamus Regency. The study was conducted in January 2020. Milk specimens were taken from farmers in Gisting Atas and Air Naningan district areas of Tanggamus Regency, Lampung Province. Specimen testing was carried out at the Animal Production Laboratory, Department of Animal Husbandry, Faculty of Agriculture, University of Lampung. Specimens of milk used were obtained from farms in the Gisting Atas region as many as 9 lactation dairy cows and 10 lactation dairy cows from farms in the Air Naningan region. This research method was a survey by taking farm data through interviews, taking milk specimens for mastitis testing with the reagents of IPB-1, taking specimens to be used as preparations which are then tested to somatic cell count using the breed method. The variables observed were the results of mastitis test and the results of somatic cell counts in dairy milk. Data were processed in tabulation and histogram then explained descriptively. The mastitis test results showed that $33 \%$ of cow nipples from Gisting Atas farms and 37\% of nipples from Air Naningan farms positively had subclinical mastitis. Calculation of the number of somatic cells showed that the average number of somatic cells was 2,341,538 cells / $\mathrm{ml}$ for the Gisting Atas area and as much as 821,176 cells / $\mathrm{ml}$ for the Air Naningan region.
\end{abstract}

Keywords: Subclinical mastitis, IPB-1 test, Breed method, Somatic cells, dairy milk

\begin{abstract}
ABSTRAK
Penelitian ini bertujuan untuk mengetahui ada tidaknya kasus mastitis subklinis dengan uji mastitis IPB-1 dan perhitungan jumlah sel somatik metode Breed pada sapi perah di Kabupaten Tanggamus. Penelitian dilaksanakan pada Januari 2020. Lokasi pengambilan spesimen susu di peternakan rakyat di wilayah Gisting Atas dan Air Naningan Kabupaten Tanggamus Provinsi Lampung. Pengujian spesimen dilaksanakan di Laboratorium Produksi Ternak Jurusan Peternakan Fakultas Pertanian Universitas Lampung. Spesimen susu yang digunakan diperoleh dari peternakan di wilayah Gisting Atas sebanyak 9 ekor sapi perah laktasi dan 10 ekor sapi perah laktasi dari peternakan di wilayah Air Naningan. Metode penelitian ini yaitu survey dengan mengambil data peternakan melalui wawancara, pengambilan spesimen susu untuk pengujian mastitis dengan reagen IPB-1 dan penghitungan jumlah sel somatik dengan metode breed. Variabel yang diamati adalah hasil uji mastitis serta jumlah sel somatik pada susu sapi. Data diolah dalam tabulasi dan histogram kemudian dijelaskan secara deskriptif. Hasil pengujian mastitis dengan IPB-1 menunjukkan bahwa 37\% putting susu dari peternakan di Gisting Atas dan 37\% dari peternakan Air Naningan positif mengalami mastitis subklinis. Perhitungan jumlah sel somatik didapat hasil rata-rata jumlah sel somatik sebesar $2.341 .538 \mathrm{sel} / \mathrm{ml}$ untuk peternakan di Gisting Atas dan 821.176 $\mathrm{sel} / \mathrm{ml}$ untuk Air Naningan.
\end{abstract}

Kata kunci: Mastitis subklinis, uji IPB-1, Metode breed, Sel somatik, Susu sapi 


\section{PENDAHULUAN}

Susu merupakan sumber protein hewani yang semakin dibutuhkan dalam meningkatkan kualitas hidup masyarakat. Susu menjadi minuman yang bergizi dilihat dari komposisi nutrisinya, yang sangat dibutuhkan bagi manusia khususnya pada perkembangan tulang anak dan menjaga kepadatan tulang pada orang dewasa. Selain bermanfaat, susu dapat juga membahayakan atau menimbulkan gangguan terhadap kesehatan manusia apabila terjadi kerusakan pada susu tersebut. Produksi susu yang rendah menyebabkan belum terpenuhinya kebutuhan susu di Indonesia. Salah satu faktor yang paling sering menyebabkan penurunan produksi dan kualitas susu adalah peradangan ambing pada sapi perah yang sering disebut mastitis (Saleh, 2014).

Mastitis merupakan peradangan yang bersifat kompleks dengan variasi penyebab, derajat keparahan, lama penyakit, dan akibat penyakit yang beragam. Mastitis subklinis adalah mastitis yang tidak menampakkan perubahan fisik pada ambing, susu yang dihasilkan, penurunan produksi susu, ambing tidak bengkak, tidak sakit ataupun panas, serta tidak terdapat kelainan tertentu pada susu sehingga sulit untuk didiagnosa (Poeloengan, 2009). Mastitis subklinis hanya dapat dideteksi melalui pemeriksaan laboratorium atau uji-uji khusus seperti California Mastitis Test (CMT) atau IPB-1 (Lukman et al., 2012). Tindakan pencegahan menjadi alternatif terbaik dalam upaya penanggulangan penyakit ini. Salah satu metode pencegahan yang efektif, terutama untuk mastitis subklinis adalah melalui pemeriksaan rutin dengan uji mastitis.

Meningkatnya jumlah sel somatis (JSS) pada kasus mastitis subklinis menjadi parameter penting untuk mendiagnosa mastitis (Sudarwanto, 1999). Peradangan atau perlukaan pada ambing menyebabkan pelepasan sel somatik dalam susu. Penghitungan JSS dipilih karena merupakan indikator terjadinya proses peradangan dalam kelenjar susu (Griffi et al., 1987; Walte dan Ubben, 2005). Jumlah sel somatik dalam susu dapat dihitung menggunakan metode, seperti metode Breed (Redetzky et al., 2005). Data mengenai kasus mastitis di Kabupaten Tanggamus belum tersedia. Berdasarkan uraian di atas, maka perlu dilakukan penelitian uji mastitis subklinis dengan menggunakan IPB-1 dan perhitungan jumlah sel somatik metode Breed.

\section{MATERI DAN METODE}

\section{Waktu dan Tempat}

Penelitian ini dilaksanakan pada Januari 2020. Lokasi pengambilan spesimen susu di peternakan rakyat di wilayah Kecamatan Gisting Atas dan Air Naningan yang berada di Kabupaten Tanggamus Provinsi Lampung. Pengujian spesimen dilaksanakan di Laboratorium Produksi Ternak Jurusan Peternakan Fakultas Pertanian Universitas Lampung.

\section{Materi}

Alat dan bahan yang digunakan adalah pipet ukur, paddle, botol kaca $10 \mathrm{ml}$, gelas objek, cover glass, pipet Breed, mikroskop cahaya, ose ujung siku, bunsen, cover glass, korek api, cooling box, plastik, kertas milimeterblock, spet $10 \mathrm{ml}$, spet $1 \mathrm{ml}$, alat tulis, susu sapi laktasi sebanyak 9 ekor untuk peternakan di Gisting Atas, dan 10 ekor dari peternakan di Air Naningan, susu sapi perah., reagen IPB-1, alkohol 96\%, alkohol 70\%, aquadest, es batu, methylen blue Loeffler, vaselin, Sapi perah

\section{Metode}

\section{Profil peternakan}

Profil peternakan diperoleh melalui wawancara menggunakan kuesioner.

\section{Pengambilan Spesimen}

Pengambilan spesimen dilakukan pada waktu pagi hari. Uji mastitis dibutuhkan $2 \mathrm{ml}$ susu dari setiap puting sapi dan perhitungan jumlah sel somatik dibutuhkan $5 \mathrm{ml}$ susu dari setiap puting sapi yang dimasukkan ke dalam botol kaca disimpan dalam cooling box dan selanjutnya dibawa ke laboratorium.

\section{Uji mastitis}

Metode uji mastitis IPB-1 yang digunakan mengacu pada Sudarwanto (2014). Sebanyak $2 \mathrm{ml}$ spesimen susu dimasukkan ke dalam paddle, kemudian ditambahkan $2 \mathrm{ml}$ reagen. Campuran spesimen susu dan reagen dihomogenkan secara horisontal selama 1530 detik. Hasil dibaca berdasarkan reaksi yang terjadi, yaitu terbentuknya lendir atau perubahan kekentalan dengan nilai negatif (-) apabila tetap homogen dan positif $(+,++,+++)$ apabila terbentuk lendir atau kental. Penialain tingkat reaksi mastitis mengacu pada Tabel 1 Foley et al., (1972). 
Tabel 1. Hubungan tingkat kekentalan terhadap perkiraan jumlah sel somatik

\begin{tabular}{ccc}
\hline Tingkat reaksi & Deskripsi reaksi & Perkiraan sel somatik/ml \\
\hline$(-)$ & tidak ada gel & $<200.000$ \\
$(+)$ & gel yang terbentuk agak tipis & $200.000-500.000$ \\
$(++)$ & gel yang terbentuk agak tebal & $500.001-1.500 .000$ \\
$(+++)$ & gel terbentuk tebal & $1.500 .001-5.000 .000$ \\
$(++++)$ & gel terbentuk sangat kental & $>5.000 .000$ \\
\hline
\end{tabular}

\section{Perhitungan Jumlah Sel Somatik}

Penghitungan jumlah sel somatik menggunakan Metode Breed yang mengacu pada Lukman et al. (2012). Gelas objek dibersihkan dengan larutan alkohol $70 \%$ dan diletakkan di atas kertas cetakan atau pola bujur sangkar seluas 1 x $1 \mathrm{~cm}^{2}$. Susu yang akan diperiksa dihomogenkan terlebih dahulu, kemudian susu dipipet menggunakan pipet Breed dan diteteskan sebanyak $0,01 \mathrm{ml}$ susu tepat di atas kotak $1 \mathrm{~cm}^{2}$. Spesimen susu disebar membentuk kotak seluas $1 \mathrm{~cm}^{2}$ menggunakan ose berujung siku. Gelas objek dikering udarakan selama 5-10 menit selanjutnya difiksasi dengan nyala api bunsen.

\section{Analisis Data}

Data profil peternakan dibuat dalam bentuk tabulasi serta data uji mastitis dan jumlah sel somatik ditabulasi dan dianalisis secara deskriptif.

\section{HASIL DAN PEMBAHASAN}

\section{Gambaran Umum Lokasi Penelitian}

Lokasi penelitian terletak di

Kabupaten Tanggamus yaitu di Kecamatan Gisting Atas dan Air Naningan. Peternakan di Kecamatan Gisting Atas dikelilingi oleh kebun sayuran milik warga setempat. Peternakan ini memiliki 10 ekor betina laktasi, betina masa kering 3 ekor, dara bunting 1 ekor, jantan tidak ada, dan pedet 7 ekor. Total populasi sapi perah adalah 21 ekor. Produksi susu hariannya sekitar 80 liter. Harga jual susu adalah Rp. 15.000/ liter.

Lokasi penelitian di Kecamatan Air Naningan, merupakan daerah yang dikelilingi oleh hamparan kebun karet seluas $3 \mathrm{Ha}$. Peternakan ini memiliki pupulasi betina bunting 9 ekor, betina masa kering 2 ekor, bunting 1 ekor, jantan 2 ekor dan pedet 8 ekor. Total populasi sebanyak 22 ekor sapi. Produksi susu hariannya sekitar 75 liter. Sedangkan untuk harga jual susu adalah $\mathrm{Rp}$. $15.000 /$ liter.

\section{Sanitasi Kandang}

Sanitasi kandang di peternakan Gisting Atas dalam sehari dilakukan dua kali dimulai pagi $04.00-04.30$ WIB untuk sore hari pukul 13.30-14.00 WIB. Sanitasi kandang di wilayah Air Naningan hanya satu kali yaitu di pagi hari pukul 07.00-07.30 WIB. Sanitasi di kedua lokasi penelitian hanya dilakukan dengan air sumur tanpa penambahan bahan desinfektan. Menurut Lukman et al. (2009), teknik sanitasi yang kurang tepat juga menyebabkan kegagalan dalam sanitasi. Sanitasi yang benar harus menggunakan desifektan agar agen pertumbuhan mikrob dapat diminimalisir.

Apabila kandang dan lingkungan bersih maka penyakit yang akan menyerang ternakpun dapat terhindari. Kesehatan ternak mempengaruhi produksi susu yang akan dihasilkan. Martindah et al. (2009), penyakit infeksius dan noninfeksius merupakan hambatan dalam upaya pencapaian produksi susu yang optimal. Salah satu penyakit infeksius yang biasa menyerang pada sapi perah akibat manajemen sanitasi kandang yang kurang baik adalah mastitits atau peradangan pada ambing.

\section{Kondisi Kebersihan Petugas Kandang dan Pemerah}

Kondisi petugas kandang di kedua wilayah tersebut termasuk yang kurang memperhatikan kebersihan. Tidak ada perlakuan khusus bagi petugas kandang sebelum melakukan aktivitas di kandang seperti mandi, membersihkan kuku agar tidak mencemari susu maupun melukai ambing, berganti pakaian menggunakan pakaian khusus kandang yang sudah bersih, dan sabun pencuci tangan untuk meminimalisir mikrob pada telapak tangan. Menurut Chye et al. (2004) bahwa cemaran mikrob bisa berasal dari pemerah.

\section{Kebersihan dan Kesehatan Ternak}

Kebersihan dan kesehatan hewan di wilayah Gisting Atas dan wilayah Air Naningan dalam keadaan kurang bersih. Pada bagian ambing terlihat masih menempelnya 
kotoran. Berdasarkan pernyataan Hadiwiyoto (1994), sapi yang tidak sehat dan tidak bersih pada waktu diperah akan menghasilkan susu yang mempunyai kandungan mikrob dalam jumlah banyak. Maka perlu dilakukan pencucian ambing serta penggunaan desinfektan pada puting agar mikrob patogen penyebab mastitis bisa dihindari. Menurut Lukman et al. (2009), kontaminasi mikrob bisa berasal dari kulit sapi, ambing, dan air yang digunakan.

\section{Sanitasi Peralatan Kandang}

Sanitasi peralatan kandang dari kedua wilayah penelitian yaitu hanya dicuci dengan air saja, tidak ada desinfektan untuk membersihkannya. Setelah itu peralatan kandang disimpan di sekitar kandang saja tidak diletakkan di ruang khusus. Pencucian peralatan pemerahan dan penanganan susu seharusnya dengan menggunakan larutan pembersih. Menurut Direktorat Jenderal Peternakan (2006), hal yang perlu diperhatikan untuk menjaga kesehatan ternak salah satunya adalah pencucian serta sanitasi semua peralatan untuk penanganan susu setelah digunakan.

\section{Penanganan Limbah Ternak}

Penanganan limbah di peternakan wilayah Gisting Atas, hanya ditampung di pembuangan yang berbentuk kubangan. Kubangan air tersebut tidak kunjung surut dengan cepat, sehingga banyak serangga lalat yang bergerumun di sekitar kubangan tersebut, karena terdapat aroma yang kurang sedap.

Berbeda dengan peternakan di Gisting Atas. Limbah peternakan di wilayah Air Naningan diolah menjadi biogas, dan dimanfaatkan untuk keperluan pasteurisasi susu. Menurut Suryowardojo et al. (2008), kejadian mastitis subklinis dapat pula dipengaruhi oleh faktor kebersihan tempat, kepadatan ternak dalam kandang, dan jarak kandang dengan rumah. Zalizar et al, (2013) mengatakan bahwa di dalam kotoran ternak segar dapat ditemukan mikrob berbahaya seperti Escherichia coli.

\section{Kegiatan saat Pemerahan}

Kegiatan pemerahan yang dilakukan oleh kedua peternakan sama-sama menggunakan mesin perah. Frekuensi pemerahan di wilayah Gisting Atas dua kali sehari (pagi dan sore hari). Wilayah Air Naningan hanya satu kali dalam sehari (pagi hari). Menurut Saleh (2014) bahwa faktor yang mempengaruhi produksi susu antara lain adalah jumlah pemerahan setiap hari, lamanya pemerahan, dan waktu pemerahan dan menurut Sudono et al. (2003), waktu pemerahan dalam sehari umumnya dilakukan dua kali, yaitu pagi dan sore.

\section{Hasil Uji Mastitis Subklinis dan Jumlah Sel Somatik}

Hasil uji mastitis subklinis dan jumlah sel somatik dari kedua lokasi peternakan Gisting Atas dan Air Naningan disajikan pada Tabel 2 dan 3. Hasil penelitian uji mastitis pada peternakan Gisting, dari total 36 puting berasal dari 9 ekor sapi diketahui 12 puting (33\%) positif mengalami mastitis subklinis dan 24 puting atau (67\%) negatif. Hasil penelitian di peternakan Air Naningan dari total 40 puting berasal dari 10 ekor sapi yang di uji mastitis, diketahui 15 puting (37\%) positif mengalami mastitis subklinis dan sisanya 25 puting $(63 \%)$ negatif. Perbandingan tingginya mastitis subklinis dari peternakan Gisting dan Air Naningan berdasarkan uji mastitis IPB-1 dapat dilihat pada Gambar 1.

Tabel 2. Hasil uji mastitis IPB-1 dan jumlah sel somatik metode Breed di peternakan Gisting Atas

\begin{tabular}{cccc}
\hline Tingkat reaksi & Standar jumlah sel somatik $* *$ & $\begin{array}{c}\text { Uji mastitis IPB-1 } \\
\text { (puting*) }\end{array}$ & $\begin{array}{c}\text { Jumlah sel somatik } \\
\text { (sel/ml/puting) }\end{array}$ \\
\hline$(-)$ & $<200.000$ & 24 & 80.000 \\
$(+)$ & $200.000-500.000$ & Tidak ada & Tidak ada \\
$(++)$ & $500.000-1.500 .000$ & 4 & $800.000-1.440 .000$ \\
$(+++)$ & $1.500 .000-5.000 .000$ & 7 & $1.520 .000-4.280 .000$ \\
$(++++)$ & $>5.000 .000$ & 1 & $7.120 .000 \mathrm{~s}$ \\
\hline
\end{tabular}

* Total puting di uji 36 (9 ekor)

** Sumber : Foley et al. (1972) 
Tabel 3. Hasil uji mastitis IPB-1 dan jumlah sel somatik metode Breed di peternakan Air Naningan

\begin{tabular}{cccc}
\hline Tingkat reaksi & $\begin{array}{c}\text { Standar jumlah sel } \\
\text { somatik } * *\end{array}$ & $\begin{array}{c}\text { Uji mastitis IPB-1 } \\
\text { (puting) }\end{array}$ & $\begin{array}{c}\text { Jumlah sel somatik } \\
\text { (sel/ml/puting) }\end{array}$ \\
\hline$(-)$ & $<200.000$ & 25 & $80.000-120.000$ \\
$(+)$ & $200.000-500.000$ & 2 & 480.000 \\
$(++)$ & $500.000-1.500 .000$ & 12 & $600.000-1.360 .000$ \\
$(+++)$ & $1.500 .000-5.000 .000$ & 1 & 1.920 .000 \\
$(++++)$ & $>5.000 .000$ & Tidak ada & Tidak ada \\
\hline & & Rata-rata & 821.176 \\
\hline
\end{tabular}

* Total puting diuji 40 (10 ekor)

** Sumber : Foley et al. (1972)

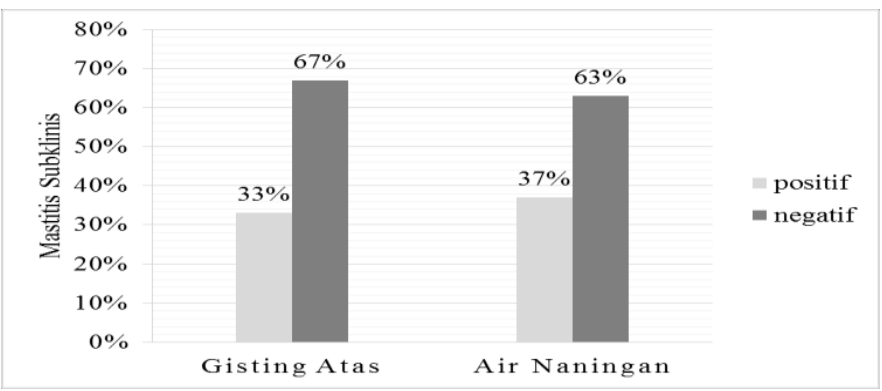

Gambar 1. Perbandingan tingginya mastitis subklinis dari peternakan Gisting dan Air Naningan berdasarkan uji mastitis IPB-1.

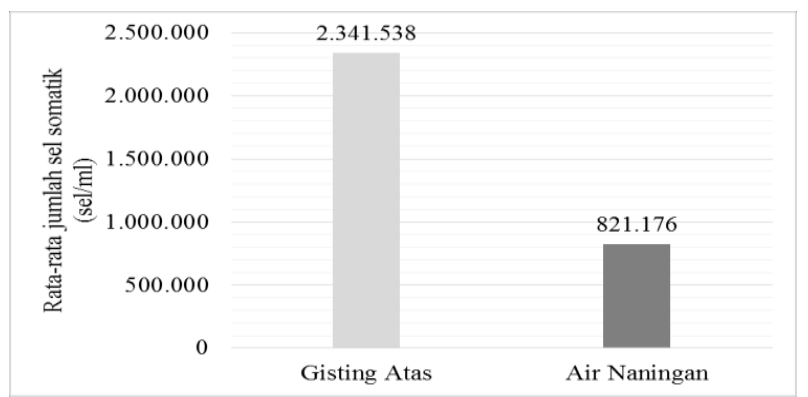

Gambar 2. Perbandingan tingginya mastitis subklinis dari peternakan Gisting dan Air Naningan berdasarkan perhitungan jumlah sel somatik metode Breed.

Jumlah rata-rata sel somatik pada sapi perah di wilayah Gisting atas sebanyak 2.341.538 $\mathrm{sel} / \mathrm{ml}$, sedangkan di wilayah Air Naningan sebanyak $821.176 \mathrm{sel} / \mathrm{ml}$. Apabila pemeriksaan jumlah sel somatik ditemukan sel somatik pada susu sapi maka dapat kita katakan sapi tersebut mengalami mastitis subklinis. Hal ini didukung oleh pendapat Suryowardojo et al. (2008), infeksi mikrob akan menyebabkan kerusakan pada jaringan kelenjar susu sehingga dapat meningkatkan pelepasan sel somatik dalam susu. Perbandingan tingginya mastitis subklinis dari peternakan Gisting dan Air Naningan berdasarkan perhitungan jumlah sel somatik metode Breed dapat dilihat pada Gambar 2.

Perhitungan jumlah sel somatik di wilayah Gisting Atas dari total 36 puting berasal dari 9 ekor sapi (Tabel 2). Diketahui 24 puting yang dinyatakan memenuhi persyaratan dengan jumlah sel somatik $\pm 80.000 \mathrm{sel} / \mathrm{ml}$ dan 12 puting dinyatakan tidak memenuhi persyaratan mutu susu segar berdasarkan SNI 3141.1 (2011), dikarenakan jumlah sel somatik berkisar $800.000-7.120 .000$ $\mathrm{sel} / \mathrm{ml}$.

Perhitungan jumlah sel somatk di wilayah Air Naningan dilakukan pada 40 puting dari 10 ekor sapi (Tabel 3). Hasil di wilayah tersebut terdapat 25 puting dinyatakan memenuhi persyaratan dengan kisaran $\pm 80.000-120.000$ $\mathrm{sel} / \mathrm{ml}$ dan 15 puting diketahui dinyatakan tidak memenuhi persyaratan SNI 3141.1 (2011) dengan kisaran 480.000-1.920.000 sel $/ \mathrm{ml}$. Menurut Lukman et al. (2009) bahwa jumlah sel somatik yang tinggi mengakibatkan penurunan kualitas susu akibat aktivitas enzimatis, yaitu protease dan lipase yang akan membuat kegagalan dalam pengolahan produk susu seperti keju. 
Sel somatik pada susu akibat infeksi mikrob dalam puting yang menyebabkan tubuh memproduksi leukosit lebih banyak untuk melawan infeksi mikrob. Hal ini sesuai dengan pendapat Sudarwanto dan Sudarnika (2008), neutrofil akan masuk ke dalam kelenjar ambing untuk melawan infeksi mikrob sehingga pelepasan sel somatik dalam susu juga akan meningkat. Perjalanan mikrob masuk kedalam saluran susu seperti yang dijelaskan oleh Subronto (2008), proses kerusakan jaringan terjadinya setelah mikrob masuk ke dalam kelenjar melalui lubang puting.

\section{KESIMPULAN}

Berdasarkan hasil penelitian, maka dapat disimpulkan bahwa puting sapi yang mengalami mastitis subklinis di wilayah Gisting atas dan Air Naningan masing-masing sebesar 33\% dan 37\%. Perhitungan jumlah sel somatik metode Breed diperoleh hasil rata-rata jumlah sel somatik sebesar $2.341 .538 \mathrm{sel} / \mathrm{ml}$ untuk wilayah Gisting Atas dan $821.176 \mathrm{sel} / \mathrm{ml}$ untuk wilayah Air Naningan. .

\section{DAFTAR PUSTAKA}

Chye, F. Y., A. Abdullah, dan M. K. Ayob. 2004. Bacteriological quality and safety of raw milk in Malaysia. Food Microbiol 21: 535-41

Direktorat Jenderal Peternakan [Ditjennak]. 2006. Statistik Peternakan. Direktorat Jenderal Peternakan. Jakarta

Griffi, N. T. K., S. V. Morant, dan F. H. Dodd. 1987. Diagnosing infectious sub clinical mastitis in surveys or large scale experiments: The analysis and interpretation of the results of an international trial organized by the IDF Mastitis Expert Group (A2). Bull. Int. Dairy Fed 211: 9-24

Hadiwiyoto, S. 1994. Pengujian Mutu Susu dan Hasil Olahannya. Liberty. Yogyakarta

Lukman, D.W., M. Sudarwanto, A.W. Sanjaya, T. Purnawarman, H. Latif, dan R. R. Soejoedono. 2009. Pengaruh mastitis terhadap kualitas susu. Dalam: Pisestyani H (editor). Higiene Pangan. FKH IPB. Bogor

Lukman D. W., M. Sudarwanto., A.W. Sanjaya., T. Purnawarman., H. Latif, dan R.R Soejoedono. 2012. Pemeriksaan Mastitis Subklinis. Dalam: Pisestyani H (editor). Higiene Pangan Asal Hewan. FKH IPB. Bogor

Martindah, E., Y. Sani, dan S. M. Noor. 2009. Penyakit Endemis pada Sapi Perah dan Penanggulangannya. http:// peternakan. litbang.pertanian.go.id. Diakses 12 November 2019

Poelongean, M. 2009. Aktivitas Air Perasan dan Ekstrak Etanol Daun Encok terhadap Bakteri yang Diisolasi dari Sapi Mastitis Subklinis. Balai Besar Penelitian Veteriner. Bogor

Redetzky, R., J. Hamman, N. T. H. Grabowsky, and G. Klein. 2005. Diagnostic Vlue of the California Mastitis Test in Comparison to Electronically Counted Somatic Cell in Bovine Milk. In: Proceeding of IDF Congress on mastitis in Dairy Production: Current knowledge and future solutions. H. Hogeveen (Ed.). Wageningen Academic Publishers, The Netherlands

Saleh, E. 2014. Dasar Pengolahan Susu dan Hasil Ikutan Ternak. Program Studi Produksi Ternak. Fakultas Pertanian Universitas Sumatera Utara. Sumatera Utara

Standarisasi Nasional Indonesia. 2011. SNI 3141.1:2011. Susu Segar-Bagian 1: Sapi. Badan Standardisasi Nasional (BSN). Jakarta

Subronto. 2008. Ilmu Penyakit Ternak. (Mammalia). Edisi ke-3. Gadjah Mada University Press. Yogyakarta

Sudarwanto, M. 1999. Usaha Peningkatan Produksi Susu Melalui Program Pengendalian Mastitis Subklinis. Orasi Ilmiah, 22 Mei 1999. Fakultas Kedokteran Hewan. Institut Pertanian Bogor. Bogor

Sudarwanto M. 2014. Pemeriksaan Mastitis Subklinis, Dalam: Pisestyani H (editor). Penuntun Praktikum Higiene Pangan Asal Hewan. Kesmavet FKH IPB. Bogor

Sudarwanto, M dan E. Sudarnika. 2008. Hubungan antara $\mathrm{pH}$ susu dengan jumlah sel somatik sebagai parameter mastitis subklinik. J. Media Peternakan. 31 (1) : 107-113

Sudono, A., F. R. Rosdiana, dan B. S. Setiawan. 2003. Beternak Sapi secara Intensif. Agro Media Pustaka. Jakarta

Suryowardojo, P., Suyadi, L. Hakim, dan Aulani'am. 2008. Ekspresi produk susu pada sapi perah mastitis. J. Ternak Tropika. $9(2): 1-11$

Walte, H. G. dan E. H. Ubben. 2005. Counting of Somatic Cells: Results of an inter-comparison study. In: Proceeding of IDF Congress on mastitis in Dairy Production: Current knowledge and future solutions. H. Hogeveen (Ed.). Wageningen Academic Publishers. The Netherlands

Zalizar, L., R. Relawati, B. Y. Ariadi. 2013. Potensi produksi dan ekonomi biogas serta implikasinya pada kesehatan manusia, ternak dan lingkungan. J. Ilmu-Ilmu Peternakan. 23 (3): $32-40$. 